\title{
SOME IDEAS OF RESURRECTION IN THE NEW TESTAMENT PERIOD
}

\author{
By $\mathrm{J}$. W. DRANE
}

The idea that Christianity should be considered in any sense as a natural product of the world in which the first Christians lived and worked has never been especially popular among British scholars, and not without good reason: in the case of the vast majority of the supposed parallels and derivations to which attention has often been drawn by more radical scholars, the evidence is not sufficient to bear the burden of proof. But in the case of the idea of resurrection, the claims of the first Christians, that their Master had risen from the dead, can legitimately be described as the climax and consummation of a long history of religious and philosophical thought in the ancient near east.*

From the time when religious minds in ancient Babylon had first observed the cycle of the seasons and had formulated the mythical person of Tammuz, who was allegedly slain and then brought back to life by his sister/wife Ishtar, the idea of resurrection in some form or other had been indelibly imprinted on the minds of men and women throughout the whole area from Mesopotamia to Egypt, and even beyond. The partnership of Tammuz and Ishtar was paralleled in Egypt by Osiris, who was slain by Set and restored by Isis and Nephthys, in Canaan by Baal and Anat, and even in Greece in the person of Persephone. According to some, the idea had also passed into the religion of Israel and, even if this is an exaggerated claim, it is at least obvious that Israel must have been familiar with such cult rituals, including the idea of resurrection. Though the ancient Babylonians and Egyptians could transfer the idea of resurrection from gods to ordinary mortals

* This paper was read at a meeting of the New Testament Study Group of the Tyndale Fellowship at Tyndale House, Cambridge, in July 1972. 
only with great difficulty, at least the first hurdle had been successfully jumped, for the average agriculturalist in the Fertile Crescent had no intellectual difficulties in accepting the idea of resurrection per se. ${ }^{1}$ Nor, contrary to popular belief, did the average worshipper in ancient Israel have too much difficulty in accepting that men could rise from the dead. There are at least three resurrection stories in the Old Testament, admittedly of a miraculous nature, but in each case the story is recorded without any expression on the part of the author(s) either of surprise or disgust at what had reputedly happened. These are the raising of the widow's son by Elijah (I Kings I $7: 17 \mathrm{ff}$.), the raising of the Shunammite's son by Elisha ( 2 Kings $4: 18 \mathrm{ff}$.), and the odd tale of the power of the same prophet's bones in 2 Kings I 3:20f.

To be sure, it is difficult to find any theological reference to resurrection in the Old Testament, and the only places in which the idea is explicitly mentioned in an abstract way, as opposed to the specific instances just noticed, are Isaiah 26:19 and Daniel 12:2, and even here the reference in Isaiah chapter 26 is somewhat uncertain, which leaves us only with Daniel 12:2. Yet we cannot take this to mean that man in ancient Israel was disinterested in the idea of resurrection, or that he somehow viewed it as an inferior form of belief, for there is no passage in the Old Testament which explicitly excludes resurrection from the beliefs of Israel. Rather is it that the emphasis is placed in a somewhat different direction, a direction largely determined by the distinctive element of Old Testament religion, namely the covenant relationship of Israel with her God. Because of this, the nation tended to take precedence over the individual, who could explain his own life in a meaningful way only in relation to the other members of his community. Hence, the only picture we have in the Old Testament of 'life after death' (if we can call it that) is of a rather vague, shadowy existence in Sheol. Though indeed a psalmist could say of his God, 'if I make my bed in Sheol, thou art there' (Ps. 139:8), even this is merely poetic language, and there is no suggestion at all of any escape from Sheol either by resurrection or by some other means. When Samuel was

1 The kind of resurrection envisaged in these earlier cult rituals was of course very different from what later became the Christian view, but this scarcely invalidates our point that the concept of resurrection was present from an early stage. 
called up from Sheol by the medium at En-dor (I Sam. 28), so unusual was this event that it needed a special explanation. The normal existence in Sheol was not one in which a man could participate in the affairs of his living compatriots: the characteristic feature of Sheol was just the very fact that the dead person was cut off from the corporate life of his nation, and, therefore, from the blessings and privileges of its relationship to God.

It is not surprising that at the time of the New Testament there were those who, clinging faithfully to the conservative orthodoxy of their faith, refused to admit the possibility of any kind of resurrection. Such were the Sadducees and the Samaritans, though it is far from certain that they were the only adherents of this view at the time. ${ }^{2}$ More general was the view that came to prevail in Talmudic Judaism, which held the hope of resurrection as a central part of its faith. So important did the doctrine become that the Talmud explicitly states that anyone who denied the doctrine would have no share in the fact. ${ }^{3}$ But even here there is by no means a unanimous opinion as to what form the resurrection will take. According to the tractate Sanhedrin, in a reference to the account of Ezekiel 37, which had related the idea of resurrection to the spiritual life of ancient Israel, the future resurrection would be of a crudely materialistic type: 'The dead whom Ezekiel brought to life again returned to the land of Israel, married wives and begat sons and daughters.' ${ }^{4} \mathrm{Rab}$, on the other hand, is reported as saying: 'In the world to come there is neither eating nor drinking nor sexual pleasures nor strife, but the righteous with their crowns sit around the table of God, feeding on the splendour of his majesty.' 5 These two statements highlight the principal elements in the diversity of Jewish ideas of resurrection in the New Testament period. On the one hand there was the view that the literal, physical body would be raised, a view which was largely associated with Palestinian Judaism; while on the other hand, a more spiritual resurrection was often envisaged, sometimes associated with the Greek idea of the

2 There is room for hesitation here since we can judge the situation only on the basis of what evidence has survived. Since most of this was preserved because of its usefulness to later Jews and Christians, both of whom had a resurrection belief, it is quite possible that there were others who did not accept a resurrection doctrine, and for that reason no record of them has survived. See C. F. Evans, Resurrection $\mathcal{E}^{2}$ the New Testament, London (1970) 27.

'Sanh. 9oa.

Sanh. $92 \mathrm{~b}$.

${ }^{5}$ Ber. 17 a. 
immortality of the soul, a view which had its most eloquent exponents in Alexandrian Judaism. ${ }^{6}$

The materialistic view of resurrection evidently developed in the same kind of apocalyptic context as is presupposed in the book of Daniel in the Old Testament. 2 Maccabees has a frequently expressed hope of resurrection for those who had been martyred in the struggle against the enemies of God, a resurrection which was expected to take the most material form possible, of a simple restoration of what was there before death. The crude picture of Razis is typical. One of the elders of Jerusalem, he is shown devoid of his life blood, hurling his entrails into the crowd, and 'calling upon the Lord of life and spirit to give them back to him again' (14:46). The Syriac apocalypse of Baruch ( 2 Baruch) has a slightly modified view of the same kind, at a later date. Here we learn that as a man dies he enters immediately into some kind of reward or punishment in Sheol. Though this place is still thought of as an intermediate abode of the dead before the final judgment (23:5, 48:16, 52:2), it will yet involve certain degrees of either happiness or torment. When Baruch asks God how the dead will be raised, he is informed that their bodies will be resurrected in precisely the same form as they had when committed to the grave, even down to whatever defects or physical deformities they may have possessed. The purpose of this is to facilitate the recognition of the risen person, but this is only a first stage. After such recognition comes the judgment, which in turn is followed by yet another change in the aspect of the resurrection body, depending on the moral status of the person concerned. The righteous are to be transformed to a more spiritual state of eternal glory: 'they shall be made like the angels, and be made equal to the stars, and they shall be changed into every form they desire, from beauty into loveliness, and from light into the splendour of glory' (51:10). A similar view of the resurrection body is also found in 4 Ezra and, from an earlier period, in the Similitudes of Enoch. It has been supposed that this was also the kind of view held by the Pharisees at the time of Jesus. We do know from the New Testament itself that the Pharisees believed in a future resurrection, and since Paul in his defence

6 The distinction between Alexandrian and Palestinian Judaism cannot now be pressed too far, for much of the Palestinian community was thoroughly imbued with Hellenism. Cf. S. Lieberman, Hellenism in Jewish Palestine, New York (1962 $\left.{ }^{2}\right)$ But in general the distinction still retains its value in the present context. 
before Felix claimed that he was on trial for such a belief (Acts 24:20f., cf. 23:6, 26:5f.), it must presumably have had some sort of resemblance to the Christian view. According to Acts 24: I5, a basic element of this belief was that 'there will be a resurrection of both the just and the unjust', a sentiment which is certainly present in 2 Baruch $49-5^{\mathrm{I}}$ and 4 Ezra 7:32, 37. Not that this represented any real concession either to the Gentiles or to the wicked, for they were to be raised only in order that they might be condemned for ever to an even worse plight than they might otherwise have suffered! All that Josephus tells us about the Pharisees is that 'Every soul ... is imperishable, but the soul of the good alone passes into another body, while the souls of the wicked suffer eternal punishment' (BF II. 8. I4). Making due allowance for his desire to explain Jewish religion in terms of Greek philosophy, it would be possible to fit his description of Pharisaic belief into something like that of 2 Baruch. At any rate, it is fairly certain that the general resurrection expectation in the Palestinian context envisaged the restoration of a body essentially identical with that which had been placed in the grave. Though for 2 Maccabees this was the sole purpose of the resurrection, whereas in the other literature it was more as a prelude to a meaningful udgment, there was a strong feeling that resurrection must nvolve a tangible body of some kind. This feeling was, of course, directly connected to the whole Hebrew psychological outlook, in which body and soul together constituted the whole person, and neither part had the potential of independent existence. Though the term 'soul' could be used, it simply described the thing that gave life to the body. For the Jew who was faithful to his own traditions, if resurrection life implied the most perfect form of life imaginable, it must be life in the body, and in a material universe, both of which were allowed to change their external appearance, while retaining their essentially material character.

In contrast to this is the view of Alexandrian Judaism, with its most eloquent exposition in the books of Wisdom, 2 Enoch, 4 Maccabees, and the voluminous writings of Philo. The overriding factor with which we need to reckon here is that the view of this 'school' was conditioned by an extensive cosmological dualism, in which matter was irreconcilably opposed to spirit. This was largely based on the Greek view 
that only the principle of mind was immortal. While for the Jew who clung to his ancestral traditions, the life of the emotions and of the senses was of the essence of human existence, for the Jew who tried to combine a Greek and a Jewish outlook, this 'intellectual' area of man's life came to assume the supreme position. As a result matter, including the physical body, was held to be of an essentially evil nature, and so its resurrection could not be admitted. The true pneuma-self had its own pre-existence before its incorporation into a material body, and its true destiny is to be realized when finally it is released from the ties of material flesh to escape once more to the spiritual realm whence it came. Characteristic of these writers was a peculiar combination of Greek and Jewish ideas. So, while the Wisdom of Solomon can make the thoroughly Hellenistic assertion that 'a perishable body weighs down the soul, and this earthly tent burdens the thoughtful mind' (9:I5), we also discover that for the soul in this predicament, the only way of escape is through the pursuit of Wisdom: 'The beginning of wisdom is the most sincere desire for instruction, and concern for instruction is love of her, and love of her is the keeping of her laws, and giving heed to her laws is assurance of immortality, and immortality brings one nearer to God' (6:I $7 \mathrm{ff}$.), a conviction that can be directly applied by the writer so that 'Because of her I shall have immortality' (8:13). Philo likewise combined this thoroughly Greek outlook with a quite incongruous insistence on a literal observance of the Jewish law, and a future expectation which included both the return of the tribes from captivity and the establishment of a messianic kingdom. Even in this unlikely company, he still denied that there could be any resurrection of the body. Flesh is evil, and the body can only be described as the 'utterly polluted prison' of the soul (De Migr. Abr. ii). The body is the tomb of the immortal soul (Quod Deus Immut. xxxii), which on the death of its prison-house will ascend to its true abode in the realm of spirit (Sacr. Ac. v). 2 Enoch is similar, with vivid pictures of hell, and accommodation for a final judgment and the intermediate stage of Sheol, combined with a denial of any resurrection for the body, because of the soul's immortality. Here we find a similar view to that of 2 Baruch, except that the initial resurrection of the original body is omitted, and the souls of the righteous are immediately clothed in divine glory. 
It is clear therefore that alongside the view that resurrection would involve something like the physical body, there was this other view in which true liberation was to be found not in a restoration of bodily existence, but in an escape from such. The future here was not a continuation of life beyond the grave, but a liberation at death, a new birth, an ascent of the pneumaself to its original abode in the world of spirit. To have suggested to such a person that his body may be resurrected would not have been to give hope, but to remove the only possibility of salvation which lay within his religious comprehension.?

To add further complication to the situation, there is also evidence of certain Jews who seem to have held an amalgam of both these other views of resurrection. I refer to the Qumran community. In considering their beliefs we can safely lay aside the idea expressed by Allegro, that the Teacher of Righteousness had risen from the dead in a dramatic way that prefigured the resurrection of Jesus. ${ }^{8}$ Nor need we consider the view of Dupont-Sommer, that the martyred Teacher of Righteousness had already 'appeared' in 63 BC, as a divine being, as Pompey captured Jerusalem. ${ }^{9}$ Both of these suggestions are more the products of an undisciplined imagination than of an exegesis of the relevant texts. Yet even aside from such ideas, there is genuine room for disagreement, and it is as easy to find a belief in the immortality of the soul as it is to discover an expectation of a bodily resurrection. ${ }^{10}$ Nor do the descriptions of Essene beliefs (assuming the men of Qumran to have been Essenes) furnished by Josephus and Hippolytus give any very definite indications, for they also display the same equivocation. According to Josephus, the Essenes believed that the body was corruptible and material, and that the soul was immortal and eternal (BF II. viii. I I). According to Hippolytus, they believed that the persons of the dead went to a bright, airy place to await judgment, and at the judgment their bodies would rise and be united with their spirits (Ref. IX. I8ff.). It therefore seems best to suppose, in the absence of any more definite

${ }_{7}$ Cf. W. Marxsen, The Resurrection of Jesus of Nazareth, E.T., London (1970) $130 \mathrm{ff}$.

${ }^{8} \mathrm{~J}$. M. Allegro, in a talk broadcast on BBC Radio on 23 January 1956 , and elaborated with slight modifications in his book The Dead Sea Scrolls, Harmondsworth (1956) (cf. pp. 148ff.).

9 A. Dupont-Sommer, The Dead Sea Scrolls, Oxford (1952) 25-44.

10 See M. Burrows, More Light on the Dead Sea Scrolls, London (1958) 342ff., for a comprehensive summary of the various possibilities. 
information, that the men of Qumran held a view which somehow tried to combine both the immortality of the soul and the resurrection of the body. ${ }^{11}$ It is clear that the representatives of Alexandrian Judaism tried to combine various elements from their own Jewish background with other elements derived from a Hellenistic view, to form a synthesis that was not always logical, and it is a simple matter to suppose that the Qumran community did the same thing. ${ }^{12}$

Having considered the main Jewish ideas on immortality and resurrection, many scholars would consider that there is nothing more to be said about ideas of resurrection which could have had some direct bearing on the beliefs of the early Christians. This may well be true, but we can hardly ignore the not inconsiderable emphasis that has been laid by other scholars on the alleged Gnostic background of early Christianity at just this very point. For, it is argued, in giving us the earliest written account of the resurrection of Jesus (I Cor. I5), Paul was at the time opposing Gnostics in the church at Corinth, and his mode of expression is to some extent conditioned by this fact. ${ }^{13}$ Despite the valuable studies of Malcolm Peel on the character of Gnostic eschatology, ${ }^{14}$ it is still the case that the predominant Gnostic view was that represented by Simon Magus who, according to the Clementine Homilies, 'does not believe the dead will be raised' (2.22). If we could believe Ernst Haenchen, that Simon was a Gnostic before he met Christianity, the problem would easily be solved. ${ }^{15}$ Unfortunately, what we do know of this enigmatic figure is hardly sufficient to form a basis for any kind of conjecture as to his actual relationship with Gnostic ideas. Nor can we have much confidence in supposing with W. Schmithals that there was a 'pre-Christian Christ Gnosticism' which can supply the answer to every difficult problem (and many simple ones too) of New Testament interpretation. ${ }^{16}$ The fact that it is possible to find mention of some sort of 'resurrection' in Gnostic works such as the Epistle to Rheginos is of little relevance here, for the

11 Cf. M. Black, The Scrolls and Christian Origins, London (196r) 1 $36 \mathrm{ff}$.

12 Cf. A. R. C. Leaney, The Rule of Qumran and its meaning, London (1966) 62.

13 Most thoroughly worked out by W. Schmithals, Gnosticism in Corinth, E.T., Nashville/New York (1971).

${ }_{14}$ Especially his article, 'Gnostic eschatology and the New Testament', in Nov $T_{12}$ (1970) 141-165.

15 E. Haenchen, 'Gab es eine vorchristliche Gnosis?', in ZTK 49 (1952) 316-349.

${ }^{16}$ See also his Paul and the Gnostics, E.T., Nashville/New York (1972). 
term anastasis can also be found in Philo and Josephus, though it is plain that it was something far different from what the New Testament writers understood it to be. It is a logical impossibility to speak of resurrection in the sense in which Christians normally understand it if we are dealing with any sort of dualistic world-view. As often as not, the term 'resurrection' is used in such contexts to indicate the ascent of the soul after death, or some such spiritual reality.

Yet it is clear that the false views in Corinth which called forth the Pauline account of the resurrection of Jesus cannot be identified either with the standard Greek view or with any of the known Jewish views of resurrection. It is clear that the Corinthians accepted the bodily resurrection of Jesus, and so they cannot have held the Greek view. It is also clear (verses I 7-I9) that they had a hope of some kind of future life after death, though they did not expect that this was to be attained by resurrection (verse 12). The only known parallel for such a view is provided by what we know of the 'sacramental realism' of the Gnostics and, since we also know that this view was present in the situation envisaged in the Pastoral epistles (2 Tim. 2:18), the majority of interpreters have supposed that this must also be seen in the background of I Corinthians 15 . It seems plain that this is the best explanation of the situation. I Corinthians 4:8 gives positive evidence of the existence of this kind of Gnostic eschatology in Corinth, while I Clement 23-26 gives conclusive proof of the existence of such a movement in Corinth at a later date, which must presumably have had earlier antecedents. The apocryphal Acts of Paul, though of uncertain value, show the apostle fighting two Gnostic teachers in Gorinth, a prominent part of whose doctrine was the denial of the resurrection of the dead. But this does not mean that there was some pre-existent Gnostic idea of resurrection which needs to be taken into account in understanding the background of the New Testament belief, for the kind of view present in Gorinth can best be seen as a misguided, though logical application of Paul's own teaching in the epistle to the Galatians, especially passages like $2: 19 f ., 5: 24$. If this is the case, the Corinthian situation would then be the first emergence of these ideas in the context of the Christian church, and we would have no need at all to postulate their existence at an earlier stage in Paul's own ministry. Even less can we assume that 
they were widespread before the emergence of belief in the resurrection of Jesus.

In trying to mould all this information into one coherent picture, we meet insuperable problems, and the only certain thing that can be said is that in the first century there was a widespread acceptance of the idea of resurrection, or at least of survival beyond the grave. But it is impossible to go further, for there were many different views as to how this resurrection would be effected. By way of concluding this study, I would like to formulate a more precise statement of the suggestion made in the opening sentences, that the resurrection of Jesus was the culmination of a long history of thought in the religious life of the ancient near east.

If the resurrection of Jesus can be regarded as only a natural development in religious thinking, serious doubt must be cast on the historicity of the actual event, for the resurrection faith could as easily have arisen from the sanctified imagination of the apostles as from an objective account of something that actually happened. ${ }^{17}$ Yet when we look to the background of the resurrection event, we can find no real hint as to why the resurrection came to assume the central place in the Christian faith. Oddly enough, it seems to me that the Old Testament was the most promising source for the belief in the resurrection of Jesus. Though the idea of resurrection as a theological principle plays little or no part in the Old Testament, there are accounts of direct intervention by God to raise specific individuals from the dead. It can also be argued that the Servant Song in Isaiah 53:I I-12 presupposes the resurrection of the Suffering Servant, a motif which seems to have played an important part in Jesus' self-understanding. Yet when we examine the resurrection accounts of the New Testament, the nearest we come to a reference to the Old Testament is Paul's vague statement in I Corinthians I5:4 that the death and resurrection of Jesus was 'in accordance with the scriptures', though there is no indication of any Scripture that may have been applied, and the phrase is probably best taken as a conventional expression. ${ }^{18}$ There is a great contrast between the

17 W. Marxsen, op. cit., is the most recent example of this kind of approach.

18 It is traditional to suppose that a passage like Ps. r6:8ff. is in view here. This passage is quoted in Ac. 2:25ff. in this very connexion, but it cannot be taken as the 'origin' of the resurrection faith. Its implication is so vague that it could have been appropriated only after the resurrection event had occurred. For a 
passion narratives and the resurrection narratives at just this very point, for whereas the former are full of Old Testament allusions and quotations, in the latter such allusions are conspicuous by their absence. Since the church was evidently hard pressed to find any Scriptures to support belief in the resurrection, it is hardly likely that the belief itself can have been arrived at by reflection on the Old Testament. Nor is it any more likely that it had much in common with the predominant Palestinian Jewish view, that envisaged a crudely materialistic form of resurrection. The resurrection body of Jesus was thought to be capable of digesting food (Lk. 24:42f.), and therefore presumably it must have had some material character; but it could also pass through walls and closed doors (Jn 20:26ff.) - a feat which no other man has ever been able to perform in a fully physical body. The connexion of the resurrection faith of the New Testament with an Alexandrian belief in immortality is even more improbable. If the Qumran community held to both immortality of the soul and resurrection of the body, this might provide a more fruitful line of investigation, but the evidence presently available from that quarter is so uncertain that it would be hazardous to speculate. The distinctive mark of the Christian view of resurrection is the survival of the totality of human personality, and neither the Greek view of immortality nor the Palestinian view of the restoration of a merely physical form of life can provide either an adequate explanation of, or even a significant parallel to the Christian belief.

It seems best to conclude, therefore, that while many strands of contemporary belief are gathered together in the resurrection faith of the New Testament, they are without exception transformed into something quite different and, ultimately, unique. Since the disciples themselves, according to Mark 9:9f., had no idea as to what 'resurrection' could mean, it is hardly likely that they were the ones who worked out that transformation. The emphasis must be placed fairly and squarely on the resurrection accounts of the various New Testament documents, for it is certain that it was only by the resurrection of Jesus, whatever that may have been, that a

useful theological treatment of the subject, $c f$. I. Reist, 'The Old Testament basis for the resurrection faith', in $E Q 43$ (1971) 6-24. 
belief which previously lay on the circumference of the religious speculations of the time could have been brought into the centre, there to become the focal point of the entire Christian faith. 